\title{
ACRL Seeks Volunteers
}

The ACRL Committee on Appointments and Nominations and ACRL section nominating committees are seeking members who are interested in serving the association and its sections through elective or appointive positions. Persons interested in being considered for nomination or appointment or interested in making recommendations should contact a member of the appropriate committee before the Midwinter Meeting in January 1978. Persons may also complete the volunteer form on page 301 and send it to the chair of the ACRL Committee on Appointments and Nominations or to the appropriate ACRL section officer. ACRL's committees and sections and their areas of responsibility are listed in the $A L A$ Handbook of Organization, 1977-1978, which is distributed to all ALA members.

ACRL Committee on Appointments and Nominations

Chair, Calvin J. Boyer, Director of University Libraries, University of Mississippi, University, MS 38677.
Agriculture and Biological Sciences Section

Nominating Committee

Chair, Anaclare F. Evans, Cataloger, Shiffman Medical Library, Wayne State University, Detroit, MI 48201; Dolores B. Owen, Documents Librarian, University of Southwestern Louisiana, USL Box 4-0199, Lafayette, LA 70504; Irene P. White, Librarian, National Agricultural Library, 10301 Baltimore Blvd., Beltsville, MD 20705.

\section{Anthropology Section Nominating Committee}

Chair, Patricia W. Silvernail, Head, Access Services, 216 Butler Library, Columbia University, 535 W. 114th St., New York, NY 10027; David R. McDonald, Social Science Bibliographer, Farrell Library, Kansas State University, Manhattan, KS 66506; Monica Reed, Research Librarian, Wenner-Gren Foundation Library, 14 E. 71st St., New York, NY 10021.

Art Section Nominating Committee

Chair, Scott Stapleton, Art Librarian, Art Library, Goodspeed Hall, University of Chi-

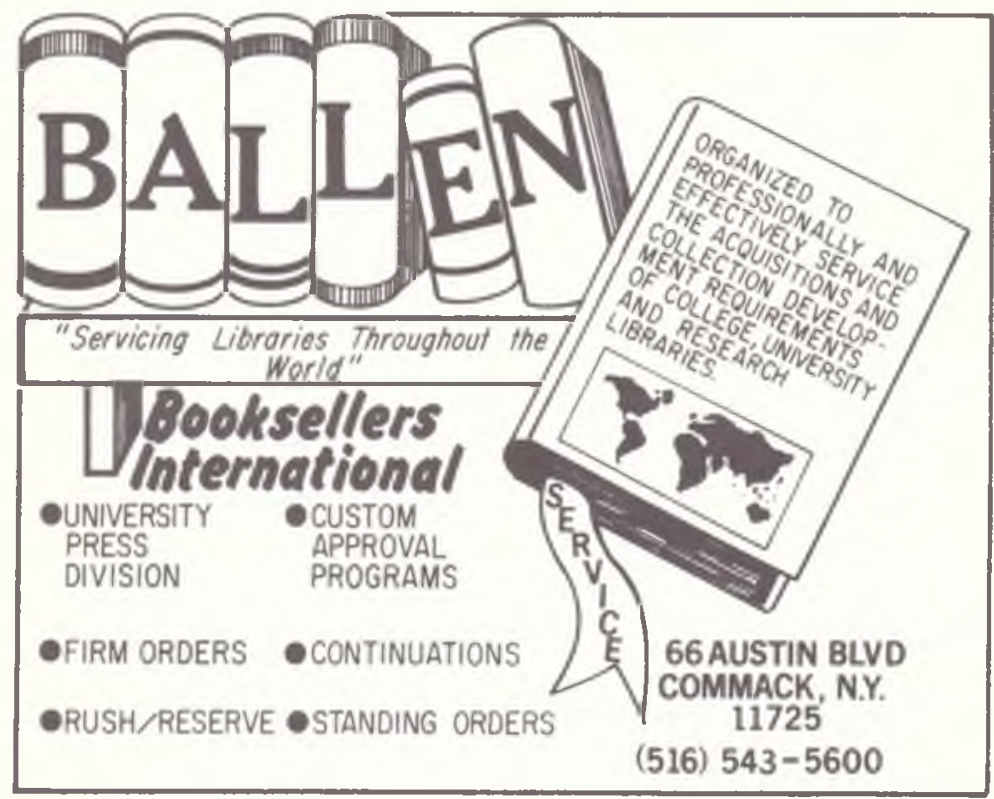


cago, 5848 Ellis Ave., Chicago, IL 60637.

Asian and African Section Nominating

Committee

Chair, Henry Scholberg, Librarian, Ames Library of South Asia, University of Minnesota, Minneapolis, MN 55455; Maidel Caison, African Documents Librarian, Northwestern University Library, Evanston, IL 60201; Y. T. Feng, Assistant Director for Research Library Services, Boston Public Library, Boston, MA 02117.

Bibliographic Instruction Section Nominating

Committee

To be appointed.

College Libraries Section Nominating

Committee

Chair, Marcy Murphy, Visiting Lecturer, Graduate School of Library and Information Sciences, University of Pittsburgh, Pittsburgh, PA 15260; Dwight F. Burlingame, Dean of Learning Resources, University of Evansville, Evansville, IN 47714; Kathlyn King Lundgren, Audio Visual Librarian, Nebraska Western College, 1601 E. 27th St., N. E., Scottsbluff, NE 69361; Murray C. Shepherd, Director of Libraries, University of Waterloo, Waterloo, Ontario, Canada N2L 3GI.

\section{Serials Updating Service}

Current information on changes and bibliographic irregularities (changes in titles and frequency, additional volumes, delays in publication, etc.) for all types of periodicals, is available in three ways:

Serials Updating Service - a monthly newsletter sent no charge to selected Faxon customers:

SUS Quarterly - a quarterly cumulation of the newsletters - $\$ 8$ one year, $\$ 15.50$ two years, \$23 three years:

SUS Annual - an annual cumulation of the newsletters - $\$ 10$.

Serials Updating Service is an invaluable resource in the acquisition, serials records, reference and binding departments, wherever serials are processed.

\section{(WA- f.U. FaXon CompanY, Inc.}

$$
\text { Publishing Division }
$$

15 Southwest Park, Westwood, Mass, 02090
Community and Junior College Libraries

Section Nominating Committee

Chair, Kathlyn King Lundgren, Audio Visual Librarian, Nebraska Western College, $1601 \mathrm{E}$. 27th St., N. E., Scottsbluff, NE 69361; Ethel B. Apple, Librarian, Elgin Community College, 1700 Spartan Dr., Elgin, IL 60120; Barbara Collinsworth, Associate Dean of Learning Resources, Macomb County Community College, Center Campus, P.O. Box 309, Warren, MI 48093; MaryCraven F. Smith, 25 Education Building, Department of Community Colleges, North Carolina State Board of Education, Raleigh, NC 27611.

Education and Behavioral Sciences Section Nominating Committee

Chair, Ruth Bauner, Associate Professor and Education/Psychology Librarian, Morris Library, Southern Illinois University, Carbondale, IL 62901; Darrell L. Jenkins, Administrative Services Librarian, Morris Library, Southern Illinois University, Carbondale, IL 62901; Lawrence W. Marble, Education Reference Librarian, Samuel Paley Library, Temple University, 13th \& Berks Streets, Philadelphia, PA 19122.

Law and Political Science Section Nominating Committee

Chair, Leslie W. Sheridan, Director of University Libraries, University of Toledo, 2801 W. Bancroft St., Toledo, $\mathrm{OH} 43606$.

Rare Books and Manuscripts Section

Nominating Committee

Chair, Georgia C. Haugh, Curator of Rare Books, William L. Clements Library, University of Michigan, Ann Arbor, MI 48109; John Bidwell, Director, Cary Collection of Graphic Arts, Rochester Institute of Technology, Rochester, NY 14623; Anne C. Skoog, Fine and Rare Books Librarian, Hunt Library, Carnegie-Mellon University, Pittsburgh, PA 15213.

Slavic and East European Section Nominating Committee

Chair, Andrew Lubomir Makuch, Bibliographer for Collection Development, University of Arizona Library, Tucson, AZ 85721; John R. James, Head, Serials Department, University of Arizona, Tucson, AZ 85721; Oleg Kudryk, Head Acquisitions Librarian, Indiana University Libraries, Bloomington, IN 47401.

University Libraries Section Nominating

Committee

Chair, Harold B. Schell, Director of University Libraries \& Dean of Library Administration, University of Cincinnati, Cincinnati, OH 45221; Patrick T. Barkey, Director of Libraries, The Claremont Colleges, Claremont, CA 91711; J. Michael Bruer, Associate University Librarian, Elmer Holmes Bobst Library, New York University, 70 Washington Square South, New York, NY 10012. 


\section{ACRL COMMITTEE VOLUNTEER FORM}

If you are interested in serving on an ACRL committee, please complete this form and return it to: Calvin J. Boyer, Director of University Libraries, University of Mississippi, University, MS 38677 .

NAME, TITLE, AND INSTITUTIONAL PREFERRED MLALING ADDRESS

ADDRESS

DATE OF APPLICATION

NUMBER OF YEARS AS MEMBER OF ALA ACRL

ACADEMIC BACKGROUND (List institutions, dates of degrees, and relevant subject areas)

PROFESSIONAL ACTIVITIES

ALA or ACRL Committee Assignments

ALA or ACRL Offices Held

Publications

Other
State and Regional Committee Assignments

State and Regional Offices Held

RELEVANT BACKGROUND OR EXPERIENCE FOR COMMITTEE ASSICNMENT

Can you attend regularly the ALA Midwinter and Annual conferences? YES NO PLEASE EXPRESS YOUR MAJOR CONCERNS FOR STRENGTHENING $\overline{T H E}$ ASS $\overline{\text { THAL. }}$ TION OF COLLEGE AND RESEARCH LIBRARIES: 